\title{
LITERATURE REVIEW: KANDUNGAN BAWANG HITAM SEBAGAI REKOMENDASI PENCEGAHAN INFEKSI IBU POSTPARTUM
}

\author{
Indah Nurhasanah $^{1^{*}}$, Febi Ratnasari ${ }^{2}$, Lastri Mei Winarni ${ }^{3}$ \\ Sekolah Tinggi Ilmu Kesehatan Yatsi ${ }^{*}{ }^{*}, 3$ \\ indahnurhasanah777@gmail.com ${ }^{{ }^{*}}$
}

\begin{abstract}
ABSTRAK
Infeksi postpartum dapat menyebabkan kematian pada ibu. Sehing ga harus dilakukan pencegahan. Salah satunya dengan mengkonsumsi makanan yang bernutrisi sehingga dapat mencegah infeksi postpartum. Tujuan penelitian ini untuk melakukan review artikel yang membahas kandungan bawang hitam untuk pencegahan infeksi ibu postpartum. Metode pada penelitian ini yaitu Jenis review yang digunakan adalah traditional review dan study literature ini menggunakan jurnal atau literature pada terbitan tahun 2016-2020 yang ditampilkan secara full text. Hasil penelitian menunjukan bahwa bawang hitam memiliki antioksidan yang tinggi dan juga kandungan nutrisi yang lengkap, seperti karbohidrat, zat besi, asam amino, protein, vitamin $\mathrm{K}$, mengandung gula (glukosa, fruktosa, sukrosa, dan maltosa) pada bawang hitam lebih tinggi dibandingkan bawang putih yang segar. Selain itu bawang hitam memiliki kandungan senyawa organosulfur yaitu S-allycysteine sehingga dapat mencegah timbulnya bakteri penyebab infeksi. Sehingga disarankan untuk melakukan penelitian lebih lanjut mengenai kebersihan proses fermentasi pada bawang putih segar.
\end{abstract}

\section{Kata Kunci : Bawang hitam, ibu nifas, infeksi}

\section{ABSTRACT}

Postpartum infection can cause maternal death. So that prevention should not be done. One of them is by consuming nutritious food so that it can prevent postpartum infection. The purpose of this study was to review articles that discussed the content of black garlic for the prevention of postpartum maternal infections. The method in this study is the type of review used is a traditional review and this literature study uses journals or literature in the 2016-2020 editions which are displayed in full text. The results showed that black garlic has high antioxidants and also a complete nutritional content, such as carbohydrates, iron, amino acids, protein, vitamin $K$, contains sugars (glucose, fructose, sucrose, and maltose) in black garlic which is higher than onions. fresh white. In addition, black garlic contains organosulfur compounds, namely $S$-allycysteine so that it can prevent the emergence of bacteria that cause infection. So it is recommended to conduct further research on the cleanliness of the fermentation process in fresh garlic.

Keywords: Black onion, postpartum mother, infection 


\section{PENDAHULUAN}

Menurut World Health Organization WHO, (2015) di seluruh dunia, sekitar 830 wanita meninggal setiap hari karena komplikasi selama kehamilan atau persalinan. Kematian ibu adalah kematian seorang perempuan yang terjadi mulai saat kehamilan sampai dengan 42 hari setelah berakhirnya kehamilan, akibat semua sebab yang terkait dengan atau diperberat oleh kehamilan atau penanganannya, tetapi bukan disebabkan oleh kecelakaan/cedera dan trauma. Penyebab kematian ibu yaitu akibat komplikasi selama kehamilan atau setelah kehamilan dan persalinan.

Komplikasi kehamilan dan persalinan di Indonesia cukup tinggi, tampak dari angka yang menunjukan bahwa $75 \%$ ibu hamil dan bersalin mengalami komplikasi. Komplikasi ini berasal dari infeksi, pre-eklamsia dan eklamsia, komplikasi dari persalinan dan abortus (World Health Organization, 2018). Komplikasi yang dialami ibu postpartum menyebabkan Angka Kematian Ibu (AKI) di Indonesia masih tinggi yaitu sebesar 305/100.000 kelahiran. Angka ini masih belum mencapai target MDGs (2015) yang mengharuskan angka AKI mencapai 102/100.000 kelahiran. Karena AKI masih cukup tinggi maka Indonesia mengikuti program SDGs yang merupakan lanjutan dari program MDGs, dimana dengan program ini diharapkan AKI pada tahun 2030 mencapai 70/100.000 kelahiran.
Kejadian kematian pada ibu di Indonesia totalnya sebesar 52,6\% yang berasal dari provinsi Banten, Jawa Barat, Jawa Timur, Jawa Tengah, Sumatera Utara, dan Sulawesi Selatan (Kemenkes, 2017). Sedangkan Angka Kematian Ibu (AKI) di indonesia pada tahun 2019 sebesar 4.221 dengan 207 kasus infeksi. Kasus infeksi tertingi di Jawa Timur dengan 38 kasus, sedangkan di Banten dengan 11 kasus (Kemenkes RI, 2020).

Upaya pencegahan infeksi postpartum dengan meningkatkan pelayanan kesehatan ibu nifas. Selain itu ibu nifas atau postpartum harus menjaga personal hygiene dan mengkonsumsi makanan yang bernutrisi (Kemenkes RI, 2020). Bawang putih yang telah diolah menjadi bawang hitam mengandung banyak nutrisi dan vitamin. Hasil dari beberapa jurnal mengatakan bahwa bawang hitam memiliki kandungan antibakteri antioksidan dan antiinflamasi yang lebih tinggi dibadingkan dengan bawang putih segar, maka dari itu penelitian ini ingin mentelaah jurnal yang sudah ada dan membahas mengenai bawang putih yang telah di fermentasi menjadi bawang hitam.

\section{METODE PENELITIAN}

Literature ini diperoleh dari hasil penelitian yang sudah dilaksanakan dan telah diterbitkan dalam jurnal online nasional maupun internasional. Menggunakan Google Scholar, Research Gate, dan NCBI 
dalam mencari jurnal yang dipublikasikan di study literature ini. Selanjutnya akan dilakukan anilisis lebih lanjut berdasarkan dengan kriteria inklusi dan ekslusi. Dalam study literature ini menggunakan jurnal atau literature pada terbitan tahun 2016-2020 yang ditampilkan secara full text. Pada pencarian jurnal tidak ditemukan jurnal yang sama dari seluruh variabel dalam literature ini. Lalu peneliti melakukan penyaringan terhadap jurnal tersebut berdasarkan kriteria yang masih memiliki hubungan dengan variabel dalam artikel ini, sehingga jurnal yang didapatkan sesuai dengan variabel yang akan di review.

\section{HASIL PENELITIAN DAN PEMBAHASAN \\ Nilai Gizi dan Aktivitas Biologi Bawang Hitam (Black Garlic)}

1. Antibakteri dan Antifungi

Penelitian yang dilakukan oleh Pujiastuti \& Palupi, (2018) dengan judul perbandingan efektivitas antibakteri minyak atsiri bawang putih (allium sativum) dan bawang hitam terhadap bakteri staphylococcus aureus dan escherichia coli dengan metode kirby-bauer. Pada penelitian ini memiliki prinsip metode dengan cara menguji diameter zona jernih di sekeliling kertas cakram yang berisi zat anti mikroba. Dalam penelitian ini didapatkan hasil bahwa baik bawang putih maupun bawang hitam mengandung minyak astiri yang memiliki daya hambat terhadap pertumbuhan bakteri Staphylococcus aureus dan Escherichia coli.

Sejalan dengan Penelitian yang dilakukan oleh Sabila et al., (2019) menunjukkan bahwa konsentrasi yang semakin besar diberikan maka daya hambat terhadap Candida albicans semakin tinggi. Pada ekstrak black garlic mempunyai respon lebih baik dari pada ekstrak bawang putih dalam memberikan hambatan pertumbuhan pada Candida albicans. Dalam black garlic mengandung S-allycysteine sehingga mempunyai sifat antibakteri yang lebih kuat serta antioksidan dua kali lebih tinggi dibandingkan dengan bawang putih segar (Shunsuke Y, 2014 dalam Sabila et all, 2019). Sedangkan S-allycysteine memiliki kandungan berupa senyawa yang disebut tiol. Senyawa ini memiliki peran yang responsif selaku antioksidan dikarenakan memiliki nukleofil didalamnya. Sehingga dapat dengan mudah menyerap proton bakteri dan menjadikan spesies tertentu menjadi inaktif. Semakin lama waktu fermentasi bawang hitam maka kandungan S-allycysteine (SAC) semakin meningkat. Dengan adanya senyawa antibakteri dalam bawang hitam yang lebih tinggi diharapkan dapat lebih efektif untuk mengatasi prokariotik patogenik penyebab penyakit seperti kandidiasis yang disebabkan oleh Candida albicans (Bae, 2010 dalam Sabila et all, 2019).

Hasil penelitian Botas et al., (2019) menunjukkan bahwa bawang 
hitam memiliki antimikroba tertinggi terutama terhadap methicillinresistant Staphylococcus aureus. Pada senyawa organosulfur yaitu allicin adalah Senyawa yang berperan sebagai antibakteri. Allicin yaitu senyawa utama asam amino yang mengandung sulfur yang tidak beraroma (Ryu \& Kang, 2017).

\section{Antioksidan}

Bawang hitam merupakan bahan senyawa yang mengandung antioksidan yaitu senyawa fenolik. Bawang hitam memiliki kandungan antioksidan yang lebih tinggi dari pada bawang putih biasa. Pada ekstrak bawang hitam memiliki macam-macam pemanasan dalam fermentasi yaitu 15, 25, dan 35 hari untuk menghasilkan aktivitas antioksidan yang tinggi yaitu kandungan senyawa aktif saponin, sterol flavonoid, dan tanin. Senyawa saponin, tanin, dan sterol dalam strukturnya mengandung gugus hidroksil bisa memberikan atom hidrogen dalam radikal bebas. Aktivitas antioksidan pada senyawa polifenol dapat mentralisir dampak radikal bebas, bahkan dapat menghentikan dampak berkelanjutan akibat dari radikal bebas. Senyawa polifenol mampu mencegah pengaruh terhadap oksidasi. Jumlah serta posisi hedrogen dalam molukulnya dapat mempengaruhi aktivitas pada daya hambat radikal bebas dalam senyawa fenol. Senyawa kuersetin merupakan jenis flavonoid yang mempunyai kemampuan dalam menangkal radikal bebas yang kuat. Senyawa ini juga dapat ditemukan pada black garlic (Ryu \& Kang, 2017).

Antioksidan yang terdapat di bawang hitam atau black garlic memiliki kandungan yang berpotensi dengan kuat. Didalamnya terkandung senyawa aktif saponin, sterol flavonoid, dan tanin, yang dapat menetralisir aktivitas radikal bebas dengan memberikan senyawa hidroksil. Lama pemanasan yang paling maksimal dalam penangkalan radikal bebas yaitu fermentasi bawang hitam dengan lama pemanasan sekitar 35 hari (Agustina et al., 2020).

Penelitian yang dilakukan oleh Resende Nassur et al., (2018) yang mengatakan bahwa pengolahan bawang putih segar menjadi bawang hitam baik secara kimia maupun fisika memiliki komposisi produk yang benar-benar berubah, yaitu dibuktikan dengan terjadinya peningkatan statistik seperti kandungan lemak, mineral, total padatan terlarut, total gula, kandungan fenolik serta aktivitas antioksidannya.

Sejalan dengan penelitian yang telah dilakukan oleh Qiu et al., (2020) bahwa adanya komponen utama selama fermentasi bawang putih segar menjadi black garlic, termasuk kelembaban, lemak, karbohidrat (seperti gula), protein, asam organik, senyawa sulfur organik, alkaloid, polifenol, melanoidins, hydroxymethylfurfural, vitamin, mineral, dan enzim. Bukti yang didapatkan menerangkan bahwa 
pada black garlic ada beberapa keunggulan dibandingkan bawang putih segar dalam atribut produk tertentu dan sifat biologis terutama pada aktivitas antioksidan. kemudian lamanya fermentasi terhadap rendemen adanya pengaruh nyata pada kadar warna kekuningan, kemerahan dan kecerahan, serta kadar air pada bawang hitam. Menurut (Putri \& Pulungan, 2020) lamanya fermentasi juga berpengaruh nyata terhadap warna yang dihasilkan oleh bawang putih yang semakin menghitam serta memiliki rasa yang lebih manis dan tekstur yang semakin tidak kenyal atau lunak serta aroma bawang hitam tidak menyengat dan stabil pada perlakuan ahri ke-10 sampai 20.

\section{Anti-inflamasi}

Penelitian yang dilakukan oleh Qiu et al., (2020) menunjukkan bahwa black garlic memiliki aktivitas anti-inflamasi yang kuat karena kaya akan anti agen inflamasi seperti OSC, polifenol, alkaloid, 5-HMF, melanoidin, polosakarida dan 2linoleoylglycero. Bukti yang diperoleh menegaskan bahwa black garlic memiliki beberapa keunggulan dibandingkan bawang putih segar. Black garlic memberikan efek antiinflamasi dengan menghambat aktivitas COX-2 dan 5lipooxygenase, sitokin pro-inflamasi, dan leukotrien (Ryu \& Kang, 2017).

\section{Pencegahan Infeksi Postpartum}

Penyebab utama kematian ibu di negara berkembang seperti Indonesia salah satunya adalah infeksi pada ibu postpartum, hal tersebut terjadi akibat dari pelayanan kesehatan yang masih jauh dari sempurna namun pemerintah sudah menerapkan berbagai peraturan untuk menngurangi kematian ibu. Infeksi postpartum dapat terjadi karena beberapa faktor diantaranya yaitu seperti, anemia, perawatan nifas yang kurang baik, daya tahan tubuh yang kurang, hygiene yang kurang baik, kurang gizi/nutrisi, serta kelelahan (Andriani, 2015). Tanda dari infeksi nifas yaitu jika terjadi peningkatan suhu $>38^{\circ} \mathrm{C}$ yang terjadi pada hari ke 2-10 hari masa nifas dan telah diukur paling sedikit 4 kali dalam sehari. Kenaikan suhu tubuh yang terjadi pada masa postpartum dianggap sebagai infeksi postpartum, jika tidak ditemukan sebab-sebab ekstra genitalia (Listinawati, 2013).

Menurut peneliti penyembuhan luka perineum yang lama akan menyebabkan infeksi pada luka perineum. Salah satu faktor lamanya penyembuhan luka perineum adalah karena pantangan makanan. Hal ini sejalan dengan penelitian Marcelina \& Nisa, (2018) bahwa penyembuhan luka perineum dapat dipengaruhi dari ibu yang berpantang makanan yang diperlukan tubuh selama masa nifas. Selain itu pantangan makan juga dapat menyebabkan kekurangan gizi pada ibu nifas yang menjadi salah satu penyebab infeksi nifas atau postpartum. Menurut Rahmanindar \& Rizqoh, (2019) dalam proses masa postpartum seharusnya ibu mau 
meningkatkan sikap positif untuk memenuhi kebutuhan nutrisinya selama nifas dengan mengkomsumsi makanan yang mengandung nutrisi yang baik sehingga mempunyai status gizi yang baik. Kekurangan protein yang disebabkan kurang nya nutrisi pada ibu postpartum akan menyebabkan terjadinya peningkatan kemampuan vasodilatasi dari pembuluh darah membentuk serabut bekuan pada tempat yang cidera.

\section{Efektivitas Black Garlic Dalam} Mencegah Terjadinya Infeksi Pada Ibu Postpartum

Infeksi pada ibu postpartum dapat dicegah dengan cara memenuhi kebutuhan nutrisi dan tidak berpantang dalam mengkonsumsi makanan. Salah satu jenis makanan yang dapat dikonsumsi oleh ibu nifas yaitu bawang hitam atau black garlic. Bawang hitam didapatkan dari hasil fermentasi bawang putih segar. Bawang hitam memiliki banyak kandungan nutrisi serta bioaktivas yang tinggi. Kandungan nutrisi ini dapat membantu meningkatkan antioksidan sehingga dapat menangkal rasikal bebas. Berdasarkan Hasil penelitian yang telah dilakukan oleh Kimura et al., (2017) bahwa terdapat peningkatan bioaktivitas black garlic dibandingkan dengan bawang putih segar dikaitkan dengan perubahan sifat fisikokimianya.

Hal ini juga sejalan dengan penelitian Resende Nassur et al., (2018) yang mengatakan bahwa pengolahan bawang putih segar menjadi bawang hitam secara kimia dan fisik memiliki komposisi produk yang benar-benar berubah, dengan peningkatan statistik menjadi komponen lipid, mineral, total padatan terlarut, total gula, kandungan fenolik dan aktivitas antioksidannya. Bawang hitam mengandung banyak nutisi, seperti karbohidrat, protein, asam amino, vitamin K, zat besi. Selain itu bawang hitam juga memiliki kandungan gula seperti glukosa, sukrosa, maltose dan fruktosa yang tinggi dibanding bawang putih biasa.

Bawang hitam atau black garlic mengandung antioksidan, antibakteri, antifungi dan antiinflamasi yang tinggi. Black garlic memiliki senyawa organosulfur, senyawa ini lah yang memiliki kemampuan untuk mencegah terjadinya infeksi. Selain itu bawang hitam atau black garlic juga memiliki rasa yang manis dan bau yang tidak menyengat (Sun \& Wang, 2018). Menurut Putri \& Pulungan, (2020) perubahan rasa dan aroma yang terjadi dikarenakan senyawa yang terdapat dalam bawang putih mengalami perubahan selama fermentasi menjadi bawang hitam.

\section{SIMPULAN}

Berdasarkan analisa yang telah dilakukan oleh peneliti pada 20 jurnal penelitian maka dapat di simpulkan bahwa bawang hitam atau black garlic efektif dalam mencegah terjadinya infeksi pada ibu postpartum. 


\section{SARAN}

Perlu dilakukan penelitian lebih lanjut mengenai kebersihan proses fermentasi pada bawang putih segar.

\section{DAFTAR PUSTAKA}

Agustina, E., Andiarna, F., \& Hidayati, I. (2020). Uji Aktivitas Antioksidan Ekstrak Bawang Hitam (Black Garlic) Dengan Variasi Lama Pemanasan. AlKauniyah: Jurnal Biologi, 13(1), 39-50. https://doi.org/10.15408/kauniya h.v13i1.12114

Botas, J., Fernandes, Â., Barros, L., Alves, M. J., Carvalho, A. M., \& Ferreira, I. C. F. R. (2019). A Comparative Study of Black and White Allium sativum L.: Nutritional Composition and Bioactive Properties. Molecules, 24(11), 2194. https://doi.org/10.3390/molecule s24112194

Kimura, S., Tung, Y. C., Pan, M. H., Su, N. W., Lai, Y. J., \& Cheng, K. C. (2017). Black garlic: A critical review of its production, bioactivity, and application. Journal of Food and Drug Analysis, 25(1), 62-70. https://doi.org/10.1016/j.jfda.20 16.11.003

Lu, X., Li, N., Qiao, X., Qiu, Z., \& Liu, P. (2017). Composition analysis and antioxidant properties of black garlic extract. Journal of Food and Drug Analysis, 25(2), 340-349. https://doi.org/10.1016/j.jfda.20 16.05.011

Marcelina, R. F., \& Nisa, F. (2018). Hubungan Antara Pantang Makanan Dengan Penyembuhan Luka Perineum Di Ruang Mawar Rsi Jemursari Surabaya. The Indonesian Journal of Health Science, 10(2), 101. Https://Doi.Org/10.32528/Ijhs.V 10i2.1862

Nelwida, N., Berliana, B., \& Nurhayati, N. (2019). Kandungan Nutrisi Black Garlic Hasil Pemanasan Dengan Waktu Berbeda. Jurnal Ilmiah Ilmu-Ilmu Peternakan, 22(1), 53-64.

Https://Doi.Org/10.22437/Jiiip. V22i1.6471

Pujiastuti, D., \& Palupi, C. (2018). Perbandingan Efektivitas Antibakteri Minyak Atsiri Bawang Putih (Allium Sativum) Dan Black Garlic Terhadap Bakteri Staphylococcus Aureus Dan Escherichia Coli Dengan Metode Kirby-Bauer. Journal Of Pharmaceutical Science And Medical Research, 1(2), 17. Https://Doi.Org/10.25273/Phar med.V1i2.2966

Putri, M. A., \& Pulungan, M. H. (2020). Evaluasi Lama Fermentasi Terhadap Karakteristik Bawang Hitam Menggunakan Camion ( Black Garlic Fermentation Machine) Evaluation Of The Black Garlic Fermentation Chracteristic Using Camion ( Black Garlic 
Fermentation Machine ). Jurnal Agroindustri, 10(2), 156-167. Https://Doi.Org/10.31186/J.Agr oind.10.2.156-167

Qiu, Z., Zheng, Z., Zhang, B., Sun-Waterhouse, D., \& Qiao, X. (2020). Formation, nutritional value, and enhancement of characteristic components in black garlic: A review for maximizing the goodness to humans. Comprehensive Reviews in Food Science and Food Safety, 19(2), 801-834. https://doi.org/10.1111/15414337.12529

Rahmanindar, N., \& Rizqoh, U. (2019). Hubungan Pengetahuan Dan Sikap Dalam Pemenuhan Kebutuhan Nutrisi Dengan Status Gizi Ibu Nifas Di Puskesmas Jatinegara Tahun 2018. Siklus : Journal Research Midwifery Politeknik Tegal, $8(1)$, 74. https://doi.org/10.30591/siklus.v $8 \mathrm{i} 1.1139$

Ratih, R. H. (2020). Pengetahuan dan Sikap Ibu Nifas tentang Perawatan Luka Perineum. Jurnal Kesmas Asclepius, 2(1), 34-43.

https://doi.org/10.31539/jka.v2i 1.592

Resende Nassur, R. de C. M., Vilas Boas, E. V. de B., \& Resende, F. V. (2018). Black garlic: transformation effects, characterization and consumer purchase intention. Comunicata Scientiae, 8(3), 444-451. https://doi.org/10.14295/cs.v8i3. 2251

Ryu, J. H., \& Kang, D. (2017). Physicochemical properties, biological activity, health benefits, and general limitations of aged black garlic: A review. Molecules, $22(6)$ https://doi.org/10.3390/molecule s22060919

Sabila, P., Ngadiani, \& Budiarti, F. F. (2019). Uji Banding Ekstrak Bawang Hitam dan Ekstrak Bawang Putih ( Allium sativum ) Sebagai Antifungi Terhadap Pertumbuhan Candida albicans. Journal of Pharmacy and Science, 4(2), 101-104.

Solehati, T., Destiani Ekautami Putri, C., Sri Pujhiyani, P., Sulistiani, E., Nur Fajari, S., Sari Wahyuni, N. S., Afifah, M., Anggia, Y., Intan, F. N., Fatmah, N., Heryadi, H., Keperawatan Universitas Padjajaran Jalan Raya Bandung Sumedang, F. K., \& Barat Indonesia, J. (2020). Pengaruh Pendidikan Kesehatan Nutrisi Pada Tingkat Pengetahuan Ibu Post Partum. An-Nadaa: Jurnal Kesehatan Masyarakat, 7(1), 27-33. https://ojs.uniska-

bjm.ac.id/index.php/ANN/articl e/view/3007

Sun, Y.-E., \& Wang, W. (2018). Changes in nutritional and biofunctional compounds and antioxidant capacity during black garlic processing. Journal 
of Food Science and Technology, 55(2), 479-488. https://doi.org/10.1007/s13197017-2956-2

Toledano Medina, M. Á., PérezAparicio, J., Moreno-Ortega, A., \& Moreno-Rojas, R. (2019). Influence of Variety and Storage Time of Fresh Garlic on the Physicochemical and Antioxidant Properties of Black Garlic. Foods, 8(8), 314. https://doi.org/10.3390/foods 80 80314

Wang, W., \& Sun, Y. (2017). In Vitro And In Vivo Antioxidant Activities of Polyphenol Extracted From Black Garlic. Food Science And Technology, 37(4), 681-685. Https://Doi.Org/10.1590/1678457x.30816

Wardhani, G. A. P. K., Azizah, M., \& Hastuti, L. T. (2020). Nilai Total Flavonoid Dalam Black Garlic (Allium Sativum L.) Berdasarkan Fraksi Pelarut Dan Aktivitas Antioksidannya. Jurnal Agroindustri Halal, 6(1), 020.

Https://Doi.Org/10.30997/Jah.V $6 i 1.2125$

Yulianisa, E., \& Mardiyah, M. S. (2019). Sikap, Keterampilan Individu, Dan Dukungan Suami Terhadap Perilaku Pencegahan Infeksi Luka Perineum Ibu Postpartum. Jurnal Ilmiah Kebidanan Indonesia, 9(04), 154-162.

Https://Doi.Org/10.33221/Jiki.V 9i04.409

Zhafira, R. (2018). Pengaruh Lama Aging Terhadap Sifat Fisik, Kimia, Dan Aktivitas Antioksidan Produk Bawang Hitam Lanang. Jurnal Pangan Dan Agroindustri, 6(1), 34-42. Https://Doi.Org/10.21776/Ub.Jp a.2018.006.01.5 